\title{
Research
}

\section{Opinions of Science Teachers about the Assessment of Talented Students in Science and Arts Centers}

\section{Bilim ve Sanat Merkezlerindeki Fen Bilimleri Öğretmenlerinin Özel Yetenekli Öğrencilerini Değerlendirmelerine Yönelik Görüssleri}

\section{Seraceddin Levent Zorluoğlư ${ }^{1}$, Yasemin Çetin ${ }^{2}$, Aybüke Aşık², Zeynep Nur Gündüz ${ }^{4}$ \& Hüseyin $\mathrm{Mertol}^{5}$}

\begin{abstract}
This study employed qualitative research method. A semi-structured interview was conducted with science teachers. Opinions of the science teachers in Science and Art Centers were taken for the evaluation of gifted students. The data obtained as a result of the interviews were analyzed by content analysis method. Teachers expressed a common view that the lessons were productive when they were acted on according to students' interests. In addition, the teaching methods and assessment tools used by the science teachers in their courses are important for the recognition of gifted students. According to the opinions of the teachers, it was determined that no specific measurement and evaluation were made for gifted students but alternative measurements and evaluation methods were used to measure the development of gifted students.
\end{abstract}

Key Words: gifted students, Science and Art Center, science, evaluation

\section{Öz}

Çalışmada özel yetenekli öğrencilere eğitim veren fen bilimleri öğretmenlerinin hangi ölçme değerlendirme yöntem ve tekniklerini kullandıkları, kullandıkları ölçme değerlendirme yöntem ve tekniklerini nasıl kullandıkları ve kullandıkları ölçme değerlendirme yöntem ve tekniklerinin öğrencilere ne düzeyde katkı sağladığını belirlemek amaçlanmıştır. Çalışma durum çalışması benimsenerek gerçekleştirilmiştir. Veri toplama aracı olarak yarıyapılandırılmış görüşme formu kullanılmıştır. Geliştirilen yarı-yapılandırılmış görüşme formu Bilim Sanat Merkezlerinde görev yapan yedi fen bilimleri öğretmenine uygulanmıştır. Elde edilen veriler içerik analizi yöntemiyle çözümlenmiştir. Öğretmenler özel yeteneklilerin ilgilerine göre hareket edildiğinde derslerin verimli geçtiği konusunda ortak bir görüş belirtmişlerdir. Ayrıca fen bilimleri öğretmenlerinin ders içinde kullandıkları öğretim yöntem ve teknikleri ve ölçme değerlendirme araçlarının özel yetenekli öğrencilerin tanınması açısından önemli olduğu söylenmiştir. Alınan görüşlere göre özel yetenekli öğrenciler için belirli bir ölçme ve değerlendirme yapılmadığ fakat özel yetenekli öğrencilerin gelişimlerini ölçebilmek için genel olarak alternatif ölçme değerlendirme yöntem ve tekniklerinin kullanıldığ belirlenmiştir.

Anahtar Sözcükler: özel yetenekli öğrenci, Bilim ve Sanat Merkezi, fen bilimleri, değerlendirme

\section{Summary}

Purpose and Significance: Science teachers and science lesson have an important impact upon integrating students into the science and technology. The aim of the science lesson is to transfer

\footnotetext{
${ }^{1}$ Correspondence Author, Assoc. Prof., Faculty of Education, Süleyman Demirel University, Isparta, Turkey; leventzorluoglu@hotmail.com, ORCID: 0000-0002-8958-0579

2 Student, Faculty of Education, Süleyman Demirel University, Isparta, Turkey, ORCID: 0000-0001-6555-5726

3 Student, Faculty of Education, Süleyman Demirel University, Isparta, Turkey, ORCID:0000-0002-7069-3709

4 Student, Faculty of Education, Süleyman Demirel University, Isparta, Turkey, ORCID:0000-0003-0854-5577

${ }^{5}$ Assist. Prof., Faculty of Arts and Sciences, Gaziosmanpaşa University, Tokat, Turkey, ORCID: 0000-0002-3507-2712

(C) Talent; ISSN 2717-7122 http://talentjournal.net
} 
science, technology and relationship of them, laws of nature and their functions to the students. The studies in the field of science make gifted students curious, make them feel excited and increase their interest into the lesson. In order to understand nature and to keep up with the developments in nature, it is required to have an academic knowledge at a certain level. Therefore, understanding and comprehension of the science lesson by the gifted individuals can be higher than normal individuals. Accordingly, the opinions of the science teachers working in the BİLSEM were evaluated to evaluate the successes of the gifted students at science lessons. The data obtained as a result of the interviews were analyzed by content analysis method. At the end of the interviews, it was determined that gifted and talented students were interested in many subjects at science lessons.

Method: Interview is used in cases where in-depth information has to be collected from individuals. The interview is divided into three groups as telephone, focus group and face to face. Telephone interview is a type of interview which is used when the researcher cannot reach the interviewees directly. Since the BILSEMs in different provinces could not be reached directly, telephone conversations made with science teachers. The aim of the interview is to determine how gifted and talented students are defined by science teachers, how to apply the methods of observing the development of gifted students in the science lesson and to what extent the applied methods contribute to the development of the students. For the constantly developing and changing science and technology, it was asked to science teachers what the expectations and suggestions of them were in science education of the gifted students. A semi-structured form was used to prepare the interview and then to ask questions to the researchers or to ask the next questions depending on the flow of the

Teachers were asked to describe the characteristics of the gifted students in order to find out how much they knew the characteristics of the audience they addressed to. Only one teacher defined as a gifted student in the BILSEM Directive to identify a gifted student for science. Only one teacher did not respond to this question because he confused the definition of gifted students with the diagnosis. Other teachers have defined gifted students as questioning, making inferences, curiosity, developing the ability of reasoning against problems and generating creative ideas.

Results and Conclusions: Teachers who acted according to the interests and inquiries of gifted students said that students enjoyed this way more and the lessons were fun. It is also important to be able to direct them to future occupational groups according to the questions of gifted and talented students. It was stated that in the course of the lecture surgery videos were followed, students were dressed according to their occupational groups and addressed them according to their occupations. Such in-class activities will increase the imagination and motivation of specially gifted students and make them more determined for their goals. According to research, it was concluded that different techniques are used in the education of gifted and talents and that enriched education and training should be given. However, considering that these students are gifted, they must be addressed during their learning. Therefore, in order to explore the gifted students, teaching methods that can be enjoyed by students in fields such as science, art and music should be applied. 


\section{Giriş}

Eğitim, bireylerin toplum içinde yerini alabilmesi için bireylerin ahlaki, fiziksel ve kişilik özelliklerine doğrudan veya dolaylı etki eden süreçtir (TDK, 2018). Bireylerdeki bu özelliklerin en iyi şekilde gelişebilmesi için en büyük pay öğretmenlere düşmektedir. Öğretmenler bu süreçte yürütücü görevi üstlenmektedir. Bu sürecin en doğru şekilde yürütebilmesi için öğretmenlerin, öğrencilerini iyi gözlemlemesi ve onların bireysel özelliklerini iyi bilmesi gerekmektedir. Öğrencilerin bireysel özelliklerini bilen öğretmen, her öğrencinin aynı seviyede olmadığını göz önünde bulundurarak eğitim-öğretim gerçekleştirebilmelidir.

Öğrencilerin akademik seviyesindeki farklılıklar ve bireysel farklılıklar dikkate alındığında, öğrenci seviyesi akranlarına göre daha üst seviyede farklılaşma gösteriyor ise bu öğrencilere özel bir eğitimin verilmesi gerekmektedir (Bildiren ve Türkkanı, 2016). Akranlarına göre bazı özellikler bakımından üst seviyede farklılaşma gösteren öğrenciler özel yetenekli öğrenci kategorisinde ele alınmaktadırlar. Özel yetenekli bireyler, zekâ kapasitesi, el becerileri, sanat ve bilime olan duyarlılı̆̆ı, yaratıcı fikirleri, bir grubu yönetebilme becerisi ve akademik alanlarda da yaşıtlarına göre üstün seviyede özellikler göstermesiyle fark edilen bireylerdir (MEB, 2015) ve bu bireylerin akranlarına kıyasla, becerilerinin bütünsel gelişime yönelik farklılaştırılmış bir eğitim almaları gerekmektedir. Bu nedenle özel yetenekli öğrencilerin eğitim ve öğretim sürecine dâhil olacak öğretmenler de bireysel farklılıkları göz önünde bulundurabilecek bakış açısına sahip olabilmeleri gerekmektedir. Çünkü özel yetenekli öğrencilerin bu özellikleri doğrultusunda özel olarak hazırlanmış eğitim programlarına, yeteneklerini geliştirebilecekleri materyallere ve nitelikli öğretmenlere ihtiyaçları vardır (Coşkun, Dündar ve Parlak, 2014).

Özel eğitim, özel eğitime ihtiyacı olan bireylerin bu ihtiyaçlarına en uygun olacak şekilde geliştirilen eğitim programları, stratejileri ve yöntemleri olan buna bağlı olarak özel olarak yetiştirilen öğretmenlerle sürdürülen eğitimdir (MEB, 2013). Bu nedenle özel yetenekli öğrencilere verilen eğitim, özel eğitim kapsamına girmektedir. Özel eğitim, özel yetenekli olan bireylerin ilgili oldukları alanlara göre en iyi yerlere gelmesini, yetersizliğin engele dönüşmemesini, engelli bireylerin ise toplum içerisinde bağımsızlaşmasını, üretken ve özgüvenli hale gelmesini hedeflemektedir (Kırcaali-İftar, 1998). Özel yetenekli öğrenciler ise onların üst düzey bilgilerinin ve üstün becerilerinin toplum tarafından olumsuz yönde kullanılmasına engel olmak amacı ile özel eğitime tabi tutulmaktadır. Bu bireylerin kendi düzeylerinin altında bir eğitim almaları durumunda bilgiyi kolay elde etmelerini sağlayacak ve bu nedenle bir süre sonra bu durum bu öğrencileri başarısızlığa yöneltebilecektir. Hem bu durumun önüne geçebilmek hem de sürekli gelişen bilim ve teknolojiye karşı bu bireylerin faydalı işler yapmasına teşvikte bulunabilmek amacıyla da bu bireyler özel eğitime tabi olmaktadırlar (MEB, 2013). Bu amaçlar doğrultusunda özel yetenekli öğrencilere özel eğitim verilebilmesi için Bilim ve Sanat Merkezleri (BİLSEM) kurulmuştur (MEB, 2016).

Fen bilimleri öğretmenlerinin ve fen dersinin gelişen bilim ve teknolojiye öğrencileri entegre etmede önemli bir etkisi vardır. Fen bilimleri dersi, bilimi, teknolojiyi ve bunlar arasındaki ilişkiyi, doğa yasalarını ve bunların işleyişini öğrencilere kazandırabilmektedir. Fen alanında yapılan çalışmalar özel yetenekli öğrencileri meraklandırmakta, onlarda heyecan uyanmasını sağlamakta 
ve onların derse karşı ilgilerini arttırmaktadır. Fen bilimleri, doğayı anlayabilmek ve doğadaki gelişimlere ayak uydurabilmek için belli bir akademik bilgiye sahip olmak gerekmektedir. Bu yüzden özel yetenekli bireylerin fen bilimlerini anlamaları ve işleyişini kavramaları normal seviyedeki bireylere göre daha yüksek olabilmektedir (Erdoğan ve Kahveci, 2015).

Fen bilimleri dersinde diğer derslerde de olduğu gibi öğretmen, öğrenciye bilgiyi doğrudan aktaran kişi değil öğrencinin bilgiyi yapılandırmasında rehberlik eden bir kişi olması gerekmektedir (Kaptan ve Korkmaz, 1999). Bu rehberlik sonucunda öğrenci bilgiye kendisi ulaşabilmeli ve bilgiyi yapılandırabilmelidir. Bu sayede öğrencilerin fen ile ilgili kavramları daha çabuk öğrenmesi, öğrendiği bu kavramları günlük yaşamda kullanabilmesi ve kavramlar arası ilişkiler kurarak daha kolay fen okuryazarı olabilmesi sağlanabilmektedir (Gürsakal, 2012). Bu nedenle öğrencilerin bilgiyi yapılandırma süreçleri öğretmenler tarafından iyi gözlenmeli ve bu yapılandırma sürecinde öğrencilerden alınan geri bildirimlere göre öğrencilerin ne kadar gelişim gösterdikleri belirlenebilmelidir.

Öğretmenler öğrencilerinin akademik gelişim düzeylerini ölçebilmek için konulara ve kazanımlara göre öğrencilerini bir değerlendirme süreçlerine tabi tutmaktadırlar. Özel yetenekli öğrencilerin bireysel farklılıklarından dolayı değerlendirme süreçlerinde de farklılıkların olması gerekmektedir. Bu nedenle normal seviyedeki bir öğrencinin öğrenme süreciyle ve değerlendirme süreciyle bir tutulmamalıdır. Öğrenme süreci olarak bakıldığında, normal bir öğrenci düzenli tekrarlarla konuyu kavrarken özel yetenekli öğrencilere bu durum oldukça sıkıcı gelebilir ve öğrencinin dersten soğumasına sebep olabilir. Çünkü IQ puanı yükseldikçe tekrarlama sayısı azalmaktadır (Okur ve Özsoy, 2013). Değerlendirme süreci olarak bakıldığında, bu öğrencilerdeki IQ seviyeleri göz önünde bulundurulduğunda ise öğretmen, özel yetenekli öğrencilerde geleneksel ve alternatif ölçme değerlendirme yöntemlerinin dışına çıkarak konulara ve kazanımlara göre kendisinin şekillendirdiği ölçme ve değerlendirme yöntemlerini de kullanabilmesi gerekmektedir. Özellikle fen bilimleri öğretmenlerinin bu değerlendirme sürecinde kullanabilecek birçok yöntemi olabilir. Bu nedenle çalışmada özel yetenekli öğrencilere eğitim veren fen bilimleri öğretmenlerinin hangi değerlendirme yöntemlerini kullandıkları, kullandıkları değerlendirme yöntemlerini nasıl kullandıkları ve değerlendirme yöntemlerinin öğrencilere ne düzeyde katkı sağladığını belirlemek amaçlanmıştır.

Alanyazın incelendiğinde BİLSEM'lerde görev yapan fen bilimleri öğretmenlerinin özel yetenekli öğrencilerini fen konularında kullanılabilecek değerlendirmelere dair çalışmaların bulunmadığ fakat üstün veya özel yeteneklilerin özellikleri ve bu özel öğrencilere nasıl bir eğitim verilmesi gerektiği, eğitimlerinde öğretmenlere düşen görevleri, fen bilimlerinde kullanılan öğretim yöntem ve teknikleri için özel yeteneklilerin görüşlerinin alınması, BiLSEM'lerdeki öğretmenlerin BİLSEM ve özel yetenekli öğrencilerine yönelik görüşlerinin alınması, özel yetenekli öğrencilerin BİLSEM’lere yönelik taleplerini, özel yeteneklilerin sosyal bilgiler dersine yönelik metaforik alg1larını, farklılaştırılmış fen öğretiminin özel yetenekliler üzerine etkisini ve Bilim ve Sanat Merkezine devam eden özel yetenekli öğrencilerin fen tutumlarının incelenmesini konu alan çalışmaların (Akkanat, 1999; Aktepe ve Aktepe, 2009; Ayaydın ve Ün, 2018; Bedur, Bilgiç ve Taşlıdere, 2015; Bildiren ve Türkkanı, 2016; Erdoğan ve Kahveci, 2015; Mertol, Doğdu ve Yılar, 2013; Tereci, Aydın ve Orbay, 2008) yer aldığı belirlenmiştir. Bu nedenle üstün yetenekli öğrencilerin dersle- 
rine giren fen bilimleri öğretmenleri açısından bu öğrencilerin değerlendirmesine yönelik görüşlerin belirlenmesinin daha sonra yapılacak çalışmalara yol göstermesi ve katkı sağlayacağı düşünülmektedir.

\section{Yöntem}

Çalışma, nitel araştırma yöntemlerinden durum çalışması benimsenerek gerçekleştirilmiştir. S1nırları kesin olarak belli olan bir ya da bir kaç olayın belli bir kesitinin betimlenerek derinlemesine incelenmesinde durum çalışması kullanılmaktadır (Merriam, 2013). Çalışmada BİLSEM'deki özel yetenekli öğrencilere fen bilimleri dersinde uygulanabilecek değerlendirmeler ve bu değerlendirmelerin öğrenciye ne düzeyde katkı sağlayabileceği durumlarına yönelik bir çalışma gerçekleştirilmesi amacıyla durum çalışması yöntemi kullanılmıştır.

\section{Çalışma Grubu}

Çalışma grubu Bilim ve Sanat Merkezlerinde görev yapan fen bilimleri öğretmenlerinden oluşmaktadır. Çalışma grubu ulaşılabilir örnekleme yöntemi kullanılarak seçilmiştir. Ulaşılabilir örnekleme, çalışmanın amacına uygun grubun ulaşması kolay ve hızlı, zamandan tasarruf sağlanabilecek şekilde seçilmesidir (Baltac1, 2018). Ulaşılabilir örnekleme yöntemi ile çalışma grubu belirlenirken BİLSEM'lerdeki fen bilimleri öğretmenlerinin özel yetenekli bireyler hakkında daha fazla bilgiye ve tecrübeye sahip olmaları göz önünde bulundurulmuştur. Bu yüzden çalışma grubu 2018-2019 yılında Bilim ve Sanat Merkezlerinde görev yapan ve bizimle görüşmeyi kabul eden fen bilimleri öğretmenlerinden oluşmaktadır. Görüşmelerde fen bilimleri öğretmenlerinin isimleri yer almamış öğretmenler kodlanmıştır. Öğretmenlik görev süreleri ve BİLSEM'deki görev süreleri dikkate alınarak Tablo 1 oluşturulmuştur.

Tablo 1. Çalışma Grubu Öğretmenlerin Özellikleri

\begin{tabular}{lcc}
\hline Öğretmen Kodu & Öğretmenlik Mesleğindeki Görev Süresi & BİLSEM'deki Görev Süresi \\
\hline Öğr1 & 23 yıl & 10 y1l \\
Öğr2 & 20 yıl & 4 yıl \\
Öğr3 & 22 yıl & 3 yıl \\
Öğr4 & 9 yıl & 2 yıl \\
Öğr5 & 7 yıl & 2 yıl \\
Öğr6 & 31 yıl & 2 yıl \\
Öğr7 & 13 yıl & 1 yıl \\
\hline
\end{tabular}

\section{Veri Toplama Araci}

Çalışmada veri toplamak amacıyla görüşme gerçekleştirilmiştir. Görüşme, kişilerden derinlemesine bilgi toplanması gereken durumlarda kullanılmaktadır (Yıldırım ve Şimşek, 2006). Görüşme, telefonla, odak grup ve birebir olarak üçe ayrılmaktadır. Telefonla görüşme, araştırmacının görüşme yapılacak bireylere doğrudan ulaşamadığı durumlarda kullanılan bir görüşme türüdür (Creswell, 2016). Çalışmada farklı illerdeki BİLSEM'lere doğrudan ulaşılamadığı için fen bilimleri öğretmenleriyle telefonda görüşme gerçekleştirilmiştir. Görüşmede özel yetenekli öğrencilerin fen bilimleri öğretmenleri tarafından nasıl tanımlandığı, özel yetenekli öğrencilerinin fen bilimleri dersinde gelişimini gözlemleyebilmek için nasıl yöntemler uygulanıldığı ve bu yöntemlerin öğrencinin gelişimine ne düzeyde katkı sağladığını öğrenmek amaçlanmıştır. Sürekli gelişen ve 
değişen bilim ve teknoloji için ise fen bilimleri öğretmenlerinin özel yetenekli öğrenciler için fen eğitiminde beklentilerinin ve önerilerinin neler olduğu sorulmuştur. Görüşmenin yapılışı için de araştırmacının sormayı planladığı soruları hazırlayıp fakat görüşmenin akışına bağlı olarak yan sorular sorması veya verilen cevapların detaylandırılmasını istemesi üzerine gerçekleştirilen yarı yapılandırılmış form (Ek A) kullanılmıştır.

\section{Verilerin Analizi}

Çalışmada yarı-yapılandırılmış form aracılığıyla elde edilen veriler içerik analizi yöntemi temel alınarak çözümlenmiştir. İçerik analizi verilerin derinlemesine incelenmesiyle ve önceden belli olmayan kategorilerin ve temaların ortaya çıkarılmasıyla gerçekleştirilir. Birbiri ile ilişkili ve birbirine benzeyen kavramların bir araya getirilip düzenlenerek ve anlaşllır şekilde yorumlanmasıyla analiz gerçekleştirilir (Sözbilir, 2009). Elde edilen veriler sistematik bir şekilde betimlenmiştir. Veriler toplanmış, toplanan veriler kodlanmış, kodlanan veriler ise kategoriler haline getirilmiştir. Kategoriler haline getirilen veriler tablolaştırılmış ve tablolar betimlenerek yorumlanmıştır. Verilerin betimlenmesi görüşmelerin alıntılar halinde sunulmasıyla gerçekleştirilmiştir.

\section{Bulgular}

BİLSEM’lerde görev yapan fen bilimleri öğretmenlerinin, derslerine girdikleri özel yetenekli öğrencilerinin özellikleri hakkında ne kadar bilgi sahibi olduklarını öğrenebilmek için bu öğretmenlere özel yetenekli öğrenci tanımı sorulmuştur. Özel yetenekli öğrenciler "zekâ kapasitesi, el becerileri, sanat ve bilime olan duyarlılı̆̆ı, yaratıc fikirleri, bir grubu yönetebilme becerisi ve akademik alanlarda da yaşıtlarına göre üstün seviyede özellik göstermesiyle fark edilen bireyler" olarak tanımlanmaktadırlar (MEB, 2015). Öğretmenlerden alınan cevapların bu tanıma uygunluğuna bakılarak Tablo 2 oluşturulmuştur. Öğretmenlerin vermiş oldukları tanımların büyük bir çoğunluğu örtüşüyorsa "tanımı doğru yapanlar" kategorisine, tanıma yakın bir tanım yapan öğretmen cevapları "tanımı kısmen doğru yapanlar" kategorisine ve tanımı yanlış yapan öğretmen cevapları "tanımı yanlış yapanlar" kategorisine yerleştirilmiştir.

Tablo 1. Öğretmenlerin Özel Yetenekli Öğrenci Tanımını Bilme Durumları

\begin{tabular}{|c|c|c|}
\hline Kategori & Frekans & Örnek Öğretmen Cevabı/Cevapları \\
\hline $\begin{array}{l}\text { Tanımı Doğru } \\
\text { Yapanlar }\end{array}$ & 0 & $\begin{array}{l}\text { Öğretmenlerden alınan görüşler içerisinde Bilsem Yönergesi'ne (2015) göre } \\
\text { özel yetenekli öğrenci tanımını tamamen doğru yapan görüş bulunmamak- } \\
\text { tadır. }\end{array}$ \\
\hline $\begin{array}{l}\text { Tanımı Kısmen } \\
\text { Doğru } \\
\text { Yapanlar }\end{array}$ & 6 & $\begin{array}{l}\text { Öğr1: “Fazla sorgularlar, çıkarım yaparlar, bir sonraki dersi sorgularlar, } \\
\text { değişik farklı şeyler üretirler.” } \\
\text { Öğr6: “Adalet duyguları çok fazla, çok kolay kavrayan, farklı düşüncelere } \\
\text { sahip, çok soru soran öğrenciler.” }\end{array}$ \\
\hline $\begin{array}{l}\text { Tanımı Yanlış } \\
\text { Yapanlar }\end{array}$ & 1 & $\begin{array}{l}\text { Öğr3: “Özel yetenekli öğrenciyi biz tanımlamıyoruz, tanımlanmaları } 2 \text { aşa- } \\
\text { malı sınavla yapılıyor.” (Özel yetenekli öğrenci tanımı ve özel yetenekli öğ- } \\
\text { renciyi tanılama sürecini karıştırarak. Özel yetenekli öğrencilerin tanılanma } \\
\text { sürecini kısmen beyan eden öğretmen özel yetenekli öğrenci tanımında bu- } \\
\text { lunmamıştır.) }\end{array}$ \\
\hline
\end{tabular}

Tablo 2'ye göre altı öğretmen üstün yetenekli öğrenci tanımını kısmen doğru tanımlarken bir öğretmen tanım yapamamıştır. 
Fen bilimleri öğretmenlerine fen dersinde özel yetenekli öğrencilerin derse karşı ilgilerinin ne düzeyde olduğunu farkına varabilmek adına özel yetenekli öğrencileri fen dersinde nasıl tanıdıkları veya tanımladıkları sorulmuştur. Bir öğretmen fen dersi için özel yetenekli öğrenciyi tanımlamada Bilsem Yönergesi'nde bulunan özel yetenekli öğrenci tanımı (MEB, 2015) yapmıştır. Bir öğretmen ise özel yetenekli öğrenci tanımını, tanılamayla karıştırdığı için bu soruya yanıt vermemiştir. Beş öğretmen ise özel yetenekli öğrencileri soran, sorgulayan, çıkarımlar yapabilen, merak eden, problemlere karşı mantık yürütme becerisi gelişmiş olan, yaratıcı fikirler üretebilen bireyler olarak tanımlamışlardır. Örneğin Öğr1: “Fene çok meraklıdırlar, doğaya ilgilidirler. Doğal olayları sorgularlar bununla ilgili çıkarımlar yaparlar, doğaüstü olayları da sorgularlar uzayı evreni çok sorgularlar." şeklinde tanımlamıştır.

Özel yetenekli öğrencilerin fen bilimleri dersinde hangi konulara daha çok ilgili olduklarını öğrenebilmek adına 'özel yetenekli öğrencilerin fen bilimleri derslerinde hangi konulara daha çok ilgi duymaktadır?' soru sorulmuştur. Öğretmenlerden alınan cevaplara göre Tablo 3 oluşturulmuştur.

Tablo 2. Özel Yeteneklilerin Fen Derslerinde Hangi Konulara İlgili Olduklarına Dair Görüşler

\begin{tabular}{lc}
\hline Kategori & Frekans \\
\hline Astronomi (Uzay, gezegenler, dünyanın oluşumu) & 6 \\
Biyoloji (DNA, ekosistem, çevre, mikroskobik canlılar, organlar) & 4 \\
Kimya ( Maddenin yapısı ve atomlar, kimyasallar) & 3 \\
Fizik (Elektrik, elektronik, özel görelilik, rölativite, dalga denklemleri) & 3 \\
Bilinmezlikler & 2 \\
Yer bilimleri & 1 \\
Bilim adamları ve hayatı (Michael Faraday, Lavoisier) & 1 \\
Denizaltı & 1 \\
Teknoloji (Robotik kodlama, android yazılım geliştirme) & 1 \\
\hline
\end{tabular}

Tablo 3'e göre öğretmenler azalan sıra ile özel yetenekli öğrencilerin Astronomi (6), Biyoloji (4), Kimya (3), Fizik (3), bilinmezlikler (2), yer bilimleri (1), bilim adamları ve hayatı (1), denizaltı (1) ve teknoloji (1) konularına daha ilgili olduklarını belirtmişlerdir:

Öğr1: "Uzay, gezegenler yani astronomi konularma, biyoloji konularına, ekosistem, çeore, bakterilere..., kimya konularına madde ve atomlar, maddenin yapısı ayrıca elektrik, elektronik..."

Öğr3: “Astronomi, bilinmezlikler üzerine kurgu, dalga denklemleri, özel görelilik teorisine, rölativite teorisine, Michael Faraday ve hayatı, Lavoisier'in başının kesilme hikâyesi, robotik kodlama, android yazılım geliştirme oyun vb. şeyler için."

Öğr4: “...kimi fizik konularından hoşlanıyor, kimi kimya bazıları astronomi ve yer bilimleriyle...”

Özel yetenekli öğrencilerin ilgi alanlarına göre nasıl bir ortamda ders almaları gerektiğine dair öğretmenlere "Özel yetenekli öğrencilerin fen eğitimi için nasıl bir ortam sağlanmalıdır?" sorusu yöneltilmiştir. Alınan cevaplar üzerine Tablo 4 oluşturulmuştur.

Tablo 4'e göre özel yetenekli öğrencilerin fen eğitiminde zenginleştirilmiş ve geliştirilmiş atölyelerin (4) kullanılması ve yaparak-yaşayarak öğrenebilecekleri (4) ortamların oluşturulmasına yö- 
nelik görüşler sunulmuştur. Daha sonra azalan sıra ile gezi-gözlem (3), laboratuvar (3), rahat ortam (3) ve bireysel (2) ortamların sağlanması gerektiğini belirtmişlerdir. Öğretmenler genel olarak birden fazla ortam önerisinde bulunmuşlardır:

Öğr5: “Özellikle gözlemleyebilecekleri bir ortam, laboratuvar olabilir, doğa olabilir ... sinffta onlara inceleyebilecekleri örnekler verilmeli ya da kendilerinin yapabilecekleri örnekler verilmeli."

Öğr6: "Bireysel çalışacakları, özel malzemelerin olacağı, yaparak yaşayarak öğrenecekleri rahat bir ortam."

Tablo 3. Özel Yeteneklilerin Fen Eğitimi İçin Oluşturulabilecek Ortam Görüşleri

\begin{tabular}{lc}
\hline Kategori & Frekans \\
\hline Zenginleştirilmiş ve geliştirilmiş atölyeler & 4 \\
Gezi-Gözlem ortamları & 3 \\
Laboratuvar & 3 \\
Yaparak-Yaşayarak öğrenebilecekleri ortam & 4 \\
Bireysel çalı̧ılabilecek & 2 \\
Fikirlerin özgür ifade edilebildiği, rahat bir ortam & 3 \\
\hline
\end{tabular}

Özel yetenekli öğrencilere fen derslerinin normal (geleneksel) öğretim, yöntem ve tekniklerle mi yoksa farklı öğretim, yöntem ve tekniklerle mi aktarıldığını öğrenebilmek adına öğretmenlere "Normalden farklı bir öğretim, yöntem ve teknikleri mi kullanıyorsunuz? sorusu yöneltilmiştir. Öğretmenlerden alınan cevaplara göre Tablo 5 oluşturulmuştur.

Tablo 5. Fen Bilimleri Derslerinde Uygulanılan Öğretim, Yöntem ve Teknikleri

\begin{tabular}{lc}
\hline Kategori & Frekans \\
\hline Zenginleştirme, farklılaştırma ve hızlandırma & 2 \\
Beyin fırtınası & 1 \\
Bilimsel araştırma yöntemleri & 2 \\
Geliştirici etkinlikler & 1 \\
Günlük hayat ile ilişkilendirme & 1 \\
Yaparak-Yaşayarak-Dokunarak & 2 \\
Sorgulamaya ve araştırmaya dayalı & 1 \\
Proje tabanlı öğrenme & 1 \\
Özel yetenekli öğrencilerin ilgi alanlarına yönelik & 1 \\
İşbirlikli çalışma yöntemi & 1 \\
Deney ve Gözlem & 1 \\
\hline
\end{tabular}

Tablo 5'e göre öğretmenler birden fazla öğretim, yöntem ve tekniği kullandıklarını ve kullandıkları öğretim, yöntem ve teknikleri ise farklı bir öğretim, yöntem ve tekniği olarak beyan etmişlerdir. Fakat bu yöntemler arasında normal (geleneksel) öğretim yöntem ve tekniklerini; Beyin fırtınası (1), günlük hayat ile ilişkilendirme (1), sorgulamaya dayalı (1), bilimsel çalışma basamakları ve yöntemleri (2), yaparak-yaşayarak-dokunarak (1), proje tabanlı (1), işbirlikli çalışma (1), deney ve gözlem (1) yöntemlerini saymışlardır. Bunlardan farklı olarak zenginleştirme, farklılaştırma ve hızlandırma (2), özel yetenekli öğrencilerin ilgi alanlarına yönelik (2) ve geliştirici etkinlikler (1) kullandıklarını belirtmişlerdir. Tablo 5'deki öğretim, yöntem ve tekniklerin hepsi fen bilimleri dersinde uygulanmaktadır. Öğretmenler görüşlerini şu şekilde beyan etmişlerdir:

Öğr1: "Zenginleştirme, farklılaştırma, beyin firtınası, bilimsel çalışma basamakları, bilimsel çalışma yöntemlerini kullanyorum." 
Öğr5: "Sorgulamaya ve araştırmaya dayalı bilimsel araştırma tekniklerinin olduğu bir yöntem kullanıyorum... Çünkü kazanım derdimiz yok sadece süreci yaşayıp, araştırmanın mantı̆̆ını anlamasını sonunda da bilgiye kendilerinin ulaşmalarm să̆hlyoruz... Deney yöntemi, gözlem yöntemi, işbirlikçi çalışma yöntemi uygulanabilir... Çünkü işbirlikçi yöntemde daha farklı bakış açıları olarak daha güzel projelerin ortaya çıktı̆̆ını görüyoruz."

Tablo 5'e göre öğretmenlerin kullandıkları öğretim, yöntem ve tekniklerden birini anlatmaları ve neden bu öğretim, yöntem ve tekniğini kullandıklarını belirtilmesi istenmiştir. Özel yetenekli öğrencilerin ilgilerine göre hareket eden 3 öğretmen örnek bir ders planı şeklinde kullandıkları öğretim, yöntem ve teknikleri örnekler üzerinden aktarmışlardır. İki öğretmen soruya yanıt vermemiş, bir öğretmen sebebiyle hızlandırma yöntemini nasıl kullandığını belirtmiş ve bir öğretmen de konudan konuya farklı öğretim, yöntem ve teknikleri kullandığını belirterek kullandığ1 yöntemleri örneklerle desteklemiştir.

Özel yetenekli öğrencilerin ilgisine ve merakına ve onların dersi ve konuları sorgulamalarına göre öğretim, yöntem ve teknikleri derse nasıl aktardıklarını anlatan örnek öğretmen görüşü:

Öğr5: "Illk olarak bir sorunla ya da problemle çocukların derse ilgisini çekiyorum. O problemi çözmek için çok hevesleniyorlar ama onlara önce araştırma yapmaları gerektiğini söylüyorum... Bir planlamasını yaptyoruz... Bunları yaparsak bu çözüme ulaşabiliriz diye fikir yürütüyorlar. Özellikle çizgisiz defter kullanyoruz. Bunun sebebi de çocukların yapacakları bir tasarım varsa çizimlerini daha detaylı görmesini sağlıyorum. Uygulama kısminda ise yardımo oluyoruz. Kendi planladikları projeyi hayata geçiriyoruz. Daha sonra ürünlerini ya da araştırmalarını sınıfta anlatıyorlar. Son olarak proje başında nasıldı ne duruma geldi bunu konuşuyoruz ..."

Özel yetenekli öğrencilerin normal öğrencilere göre daha hızlı öğrenmesinden dolayı konuları hızlandırma yaparak aktardığını söyleyen öğretmen görüşü:

Öğr4: “Hızlandırma çünkü Normal öğrencilere göre daha kolay algılayabiliyorlar, çok sorguluyorlar, soru soruyorlar bu yüzden onlarn tatmin etmek gerekiyor... Biz onlara daha üst düzey sinfflardan konular aktararak işliyoruz. Onlar kendi deneylerini yapıyorlar."

Özel yetenekli öğrencilerine işlenilen konuya göre farklı yöntemler kullanan öğretmen görüşü:

Öğr7: “... Yöntem olarak soru cevap yöntemini kullanabiliyorum. Örneğin mikroskop kullanımını öğretirken görüntü bulma, gösterip yaptırma yöntemi kullanıldı. Bu sayede kendileri görüntü bulmayı öğrendiler, preparat hazırlamayı öğrendiler. Basit makinelerde tasarım yapmalarımı istedik ..."

Fen bilimleri öğretmenlerinin özel yetenekli öğrencilerin ilerlemelerini nasıl değerlendirdikleri ve gelişimlerini ölçen bir yöntemin olup olmadığını öğrenebilmek adına fen bilimleri öğretmenlerine "Özel yetenekli öğrencilerin gelişimini ölçen yöntemler nelerdir?" sorusu yöneltilmiştir. Öğretmenlerden alınan cevaplara göre Tablo 6 oluşturulmuştur.

Tablo 6'ya göre öğretmenler özel yetenekli öğrencilerin gelişimlerini öğrencilerin iyi bir şekilde gözlemlenmesi (3), gözlemler sonucu formlar (3) doldurulması ile ölçmektedirler. Daha sonra 
azalan sıra ile öğrencilerden geri bildirimler alınması (2), portfolyo (2), performans değerlendirme (2), kavram haritaları (1), tanılayıcı dallanmış ağaç (1), proje ödevleri (1), rubrikler (1), sürecin değerlendirilmesi (1), deney raporları ve tablolarının değerlendirilmesi (1), çoktan seçmeli testler yapılması (1) ile kontrol etmektedirler. Kullanılan yöntemlerin hepsi fen bilimleri dersinde de uygulanmaktadır. Örnek öğretmenler görüşlerini şu şekildedir:

Öğr1: “Çok İyi gözlem yapabilmek ve onlarn gözlemlerimize göre değerlendirmek, portfolyo dosyalar, her etkinliğin sonunda geri bildirim alırım, bir tartışma yapıldı mesela sınıfta konuyu inceledik, sorguladık, beyin firtınası yaptık bunun bile geri bildirimini alıyorum."

Öğr6: "Bakanlığın gönderdiği bireysel ölçekler üzerinden ilerliyoruz. Özellikle akran değerlendirmesi, öz değerlendirme, rubrik, performans ve portfolyo gibi ölçekler kullanıyorum."

Tablo 6. Fen Bilimleri Derslerinde Uygulanılan Öğretim, Yöntem ve Teknikleri

\begin{tabular}{lc}
\hline Kategori & Frekans \\
\hline Geri bildirim alarak & 2 \\
Çoktan seçmeli testler & 1 \\
Gözlem yaparak & 3 \\
Süreç değerlendirme & 1 \\
Deney raporları & 1 \\
Formlar (Akran değerlendirme, öz değerlendirme, gelişim, etkinlik) & 3 \\
Portfolyo & 2 \\
Kavram haritası & 1 \\
Tanılayıcı dallanmış ă̆aç & 1 \\
Performans değerlendirme & 2 \\
Rubrik & 1 \\
Proje ödevleri & 1 \\
\hline
\end{tabular}

İki öğretmen özel yetenekli öğrencilerin gelişimini ölçebilmek için belirli bir yöntem kullanmadıklarını belirtmişlerdir. Belirli bir yöntemleri olduğunu beyan eden öğretmenlere kullandıkları yöntemlerin özel yetenekli öğrenciye ne gibi faydalarının olduğunu öğrenebilmek adına "Kullandığınız bu değerlendirme aracı öğrencinin gelişimine ne düzeyde katkı sağlıyor?" sorusu yöneltilmiştir. Öğretmenlerden alınan cevaplar üzerine Tablo 7 oluşturulmuştur.

Tablo 7. Kullanılan Değerlendirme Araçlarının Özel Yetenekli Öğrencinin Gelişimine Katkısı

\begin{tabular}{lc}
\hline Kategori & Frekans \\
\hline Özel yetenekli öğrencinin tanınması (İlgi alanı, istekleri) & 3 \\
Gelişimini doğru yönde ilerletebilmek & 1 \\
Konuları ne düzeyde öğrendiğini bilmek & 2 \\
Değerlendirme sonuçlarının veliler ile paylaşması & 1 \\
Özel yetenekli öğrencinin hangi noktada olduğunu bilmek & 1 \\
\hline
\end{tabular}

Tablo 7' ye göre öğretmenler yapılan değerlendirmelerin özel yetenekli öğrencinin tanınmasını (3), gelişiminin doğru yönde ilerleyebilmesini (1), konuları ne düzeyde öğrendiğinin bilinmesini (2) ve özel yetenekli öğrencinin hangi noktada olduğunun bilinmesini (1) sağladığını söylemişlerdir. Öğretmenlerden biri bu değerlendirme sonuçlarının velilerle paylaşıldığı zaman yararlı geldiğini belirtmiştir. Tablo 7’ye yönelik örnek öğretmenler cevaplarını şu şekildedir:

Öğr1: “Biz gözlem yapıp değerlendirir velileri bilinçlendiririz o zaman yararlı hale gelir. Onların ilgilerinin merakların tespit eder o yönde yönlendirip önünü açmıs oluruz. Gelişimlerini doğru yönde ilerlemele- 
rine rehber oluruz."

Öğr4: "Öğrencilerin hangi noktada olduğunu gelişimde yavaşlama mı var gerileme mi var onu gözleyebiliyoruz."

Son olarak öğretmenlerin özel yetenekli öğrenciler adına genel bir görüşünü alabilmek için öğretmenlere "Özel yetenekli öğrencilerin fen eğitiminde önerdiğiniz görüşler nelerdir?" sorusu yöneltilmiştir. Alınan görüşler üzerine Tablo 8 oluşturulmuştur.

Tablo 8. Öğretmenlerin Özel Yetenekli Öğrencilerin Fen Eğitimi İçin Görüşleri

\begin{tabular}{lc}
\hline Kategori & Frekans \\
\hline Nitelikli ve rehber öğretmen (Yaratıcı düşünebilen, açık fikirli) & 2 \\
Zenginleştirilmiş atölyeler (Farklı materyaller ve farklı ortamlar) & 1 \\
Nitelikli öğrenci yetiştirebilmek (Özgüvenli ve geleceğe yönelik) & 2 \\
BİLSEM'lerin iyi yönetilmesi ve gelişmiş olması & 1 \\
Yaparak-yaşayarak öğrenme & 2 \\
Zenginleştirilmiş kütüphaneler & 1 \\
\hline
\end{tabular}

Tablo 8'e göre özel yeteneklilerin fen eğitimi için öğretmenler, nitelikli öğretmenlerin olması (2), laboratuvarların ve atölyelerin zenginleştirilmiş olması (1), nitelikli öğrenciler yetiştirilebilmesi (2), öğrencilerin yaparak-yaşayarak öğrenmesi (2) ve öğrencilerin araştırmalarını daha sağlıklı yapabilmeleri için zenginleştirilmiş kütüphaneler olması gerektiğini (1) belirtmişlerdir. Bir öğretmen BILLSEM'lerin iyi bir şekilde yönetilmesi ve her yönüyle daha gelişmiş olması gerektiğini belirtmiştir. Öğretmenler görüşlerini şu şekilde ifade etmişlerdir:

Öğr2: “... Mesela uzay konusunu uzay atölyesinde almaları, sıradışı materyallerle çalışmanın önemli olduğunu düşünüyorum ve bunların onları daha çok geliştirebileceklerini düşünüyorum."

Öğr3: “... Yaparak-yaşayarak önemli... Kendine olan özgüvenini yerine getirmek lazım.”

Öğr5: “... Ne kadar çok farklı ortam gösterirsek, farklı problem durumu yaratırsak, gelecek için daha güzel mesleklere sahip olmaları sağlanabilir."

\section{Sonuç, Tartışma ve Öneriler}

Bu çalışmada BİLSEM'lerde görev yapan fen bilimleri öğretmenlerinin özel yetenekli öğrencilerini değerlendirmelerine yönelik görüşler alınmıştır. Çalışmada fen bilimleri öğretmenlerin hemen hemen hepsinin özel yetenekli öğrenci tanımını kısmen doğru ifade ettiği belirlenmiştir. Özel yetenekli öğrenciler ile çalışan öğretmenlerin hangi öğrenci grubuyla çalıştığını bilmesi ve öğrenci ihtiyaçlarına uygun olacak şekilde donanıma ve niteliğe sahip olması gerektiğinden dolayı fen bilimleri öğretmenlerinin özel yetenekli öğrenci tanımını ve özelliklerini iyi bilmeleri gerekmektedir. Özel yeteneklilerin özelliklerini bilmeyen ya da bu koşulların gerektirdiklerini yapamayan öğretmenlerin bu özel yetenekli öğrenciler üzerinde olumsuz etki oluşturabilecekleri bilinmektedir (Satmaz ve Gencel, 2016). Bu nedenle bu öğrencilere daha iyi eğitim verilebilmesi, çalışılan grubun özellikleri ve gereksinimleri hakkında bilgi sahibi olunması için BiLSEM'lerde görev yapan öğretmenlere bu öğrencilerin özelliklerinin tanımlanması vb. durumları kapsayan eğitim verilebilir. 
Fen bilimleri dersi için Bilsem Yönergesi'nde (MEB, 2015) belli bir tanımlama yapılmamışken görüşmelerin gerçekleştirildiği fen bilimleri öğretmenleri fen derslerinde özel yetenekli öğrenciyi soran, sorgulayan, çıarımlar yapabilen, merak eden, problemlere karşı akıl yürütme becerisi gelişmiş olan, yaratıcı fikirler üretebilen bireyler olarak tanıdıklarını belirtmişlerdir. Özel yetenekli öğrencilerin derslerinde nasıl özellikler gösterdiğini bilen öğretmenler ders içi kazanımlarını doğru yönde ilerletebilmektedirler. Bu sayede toplumların gelişmesinde önemli katkılar sağlayabilecek üstün yeteneklere sahip bireylerin sahip olduğu beceriler verimli ve etkin bir şekilde kullanılabilecektir (Kontaş ve Yağcı, 2016).

Özel yetenekli birçok öğrencinin fen bilimlerine ve fen konularına ilgi duydukları farklı çalışmalarla ortaya konulmuştur (Kahyaoğlu ve Pesen, 2013). Yapılan bu çalışmada ise özel yetenekli öğrencilerinin fen derslerinde astronomi, biyoloji, fizik, kimya, bilinmezlikler, yerbilimleri, denizaltı, bilim adamları ve hayatı, teknolojik konulara ilgili olduklarını belirlenmiştir.

Öğrenciler bazı ortamlarda yapılan etkinliklerden hoşlanırken bazı etkinliklere katılmakta çekimser kalmaktadır (Şimşek, 2002). Bu nedenle öğrencilerin bireysel özellikleri dikkate alınarak gerçekleştirilen öğretim sayesinde öğrenme daha kalıcı ve daha etkili olmaktadır. Çalışmada özel yetenekli öğrencilerinin fen öğrenmelerinin sağlanacağı ortama yönelik öğretmenler zenginleştirilmiş atölyeler, gezi-gözlem ortamları, laboratuvar, yaparak-yaşayarak öğrenebilecekleri, bireysel çalışılabilecek özgür ve rahat bir ortamın sağlanması gerektiğini belirtmişlerdir. Bu görüşler arasında zenginleştirilmiş ve geliştirilmiş atölyeler, yaparak-yaşayarak öğrenebilecekleri bir ortam görüşleri ön plana çıkmıştır. Özel yetenekli öğrencilerin ihtiyaçlarının dikkate alınmadığ öğrenim ortamlarında öğretimin gerçekleştirilmesi bu öğrencilerin yeteneklerinin zamanla azalmasına, öğrenim gördükleri ortamın onlara sıkıcı gelmesinden dolayı bir süre sonra psikolojik anlamda sorunlar yaşamalarına ve buna bağlı olarak mutsuz bireylere dönüşmesine sebep olacağı bilinmektedir (Satmaz ve Gencel, 2016). Bu nedenle üstün yetenekli öğrencilerin öğretiminde üst düzey sınıf ve yeterli miktarda materyallerin kullanılması uygun olabilir.

Özel yetenekli öğrencilerin fen bilimleri derslerinde merak uyandıracak öğrenme yöntemleri, öğrenme becerileri ve deneyimlerinin geliştirilmesine yönelik olumlu yönlendirmeler arttıkça fen bilimleri derslerine yönelik tutumları olumlu yönde artış göstermektedir (Kahyaoğlu ve Pesen, 2013). Çalışmada bu öğrenciler için öğretim yöntem ve tekniklerinden zenginleştirme, farklılaştırma, hızlandırma, yaparak-yaşayarak-dokunarak öğrenme ve bilimsel çalışma yöntemlerinin öğretmenler tarafından çoğunlukla kullanıldığı belirlenmiştir. Özel yetenekli öğrencilerin eğitimlerinin kaliteli hale gelmesi ve eğitimin verimliliğin artması amacıyla bu öğrencilerde zenginleştirme ve farklılaştırma yöntemlerinin kullanılması gerekmektedir. Bu nedenle üstün yetenekli öğrencilere yönelik fen derslerinde öğrenci özelliklerini destekleyici farklı öğretim yöntem ve teknikler kullanılabilir.

Kontaş ve Yağcı (2016) araştırmasında da özel yetenekli öğrenciler için öğrenci başarısını değerlendirme amacıyla herhangi bir kayıt tutulmadığı ve BiLSEM'lerin bu tür bir misyonunun olmadığ1 ifade edilmiştir. Çalışmada özel yetenekli öğrencilerin gelişimlerini ölçen yöntemler neler olduğu belirlenmeye çalışılmış ve öğretmenler çoktan seçmeli testler, gözlem yaparak, süreç değerlendirme, deney raporları, formlar (akran değerlendirme, öz değerlendirme, gelişim, etkinlik), 
portfolyo, kavram haritası, tanılayıcı dallanmış ağaç, performans değerlendirme, rubrik ve proje ödevleri cevaplarını vermiştir. Bu değerlendirme yöntemlerinden gözlem yaparak kontrol etme ve kullanılan formlar ön plana çıkmıştır. Öğretmenler öğrencilerini çok iyi bir şekilde gözlemleyerek formlar doldurduklarını belirtmişlerdir. Belli bir ölçme ve değerlendirme sistemi olmamasına rağmen öğretmenlerin genel olarak alternatif ölçme ve değerlendirme yöntemlerini öğretme ve öğrenme sürecine entegre ettikleri söylenebilir. Bu nedenle değerlendirme amaçlı olmasa da bu öğrencilerin gelişimlerine katkı sağlamak amacı ile değerlendirme yöntemlerinin öğretime entegre edilmesi faydalı olacağı düşünülmektedir.

Demirel'e (2003) göre değerlendirme, kullanılan programların ve yöntemlerin etkililiği hakkında bir karar verme sürecidir. Bundan dolayı Tablo 6'da belirtilen değerlendirme yöntemlerinin özel yetenekli öğrenciye ne düzeyde bir katkısı olduğu fen bilimleri öğretmenlerine sorulmuş ve değerlendirmelerin özel yetenekli öğrencinin tanınmasını, gelişimini doğru yönde ilerletebilmeyi, konuları ne düzeyde öğrendiğini ve öğrencinin hangi noktada olduğunu bilmeyi sağladığı söylenmiştir. Özel yetenekli öğrencilerin değerlendirilmesi için kullanılan formları dosyalayan öğretmenlerin daha sonraki çalışmalarda öğrencide ne gibi değişikler gözlemlendiğini fark edebileceği ve öğrencisinin bu şekilde ilerleyişini kontrol edebileceği söylenebilir.

Fen bilimleri öğretmenleri özel yetenekli öğrencilerin gelişimi için zenginleştirilmiş atölyeler ve araştırmak istedikleri çalışmalar için güvenilir kaynaklardan ulaşabilmeleri adına zenginleştirilmiş kütüphaneler olması, kullanılacak materyalleri de kendileri tasarlayarak yaparak-yaşayarak öğrenmeleri gerektiğini belirtilmiştir. Bu şekilde nitelikli, geleceğe yönelik, özgüvenli bireyler yetiştirilebilmesi mümkün kılınacağını belirtmişlerdir. Aynı zamanda özel yetenekli öğrencilerin eğitim kalitesi için BİLSEM'lerin ortamının ve yönetim biçimlerinin de iyi olması gerektiği söylenmiştir. Ayaydın ve Ün (2018) araştırmasında BİLSEM'lerin birçok yönden eksik olduğu ve geliştirilmesi gerektiğini ayrıca konum olarak da kütüphanelere yakın bir konumda bulunması gerektiğini ifade etmişlerdir. Bu nedenle BİLSEM’lerde öğretim gören öğrencilerin araştırmacı ruhlarının geliştirilmesi için BILSEM'lerin her açıdan zenginleştirilmesi sağlanabilir.

Genel olarak araştırma sonuçları değerlendirildiğinde BİLSEM'de görev yapan fen bilimleri öğretmenlerinin çalıştıkları öğrencilerin özelliklerini bilmelerine rağmen üstün yetenekli öğrenci tanımını kısmen yaptıkları; bu öğrencilerin daha çok astronomi dersine ilgi duydukları; fen bilimleri dersinin verilmesi için zenginleştirilmiş ortamların kullanılmasının gerektiği; öğrencilerin bireysel özelliklerinin dikkate alınarak öğretim yöntem ve tekniklerinin belirlenmesi gerektiği; bu öğrencilerin öğretim süreçlerini geliştirmek amacıyla yapılacak olan değerlendirmelerde ise alternatif ölçme değerlendirme yöntem ve tekniklerinin kullanılmasının faydalı olacağı, bu sayede öğrencilerin daha iyi tanınabileceği ve konu öğreniminde ne düzeyde olacağının belirlenmesinde faydalı olacağı; nitelikli fen eğitimi için öncelikle nitelikli öğretmenlerin olması gerektiği ve öğrencilerin yaparak yaşayarak öğrenmesi gerektiği sonucuna ulaşılmıştır.

Bu çalışmanın küçük bir fen bilimleri öğretmenlerinin oluşturduğu grubun görüşlerini yansıtıyor olması çalışmaya bir sınırlılık getirmektedir. Ayrıca fen bilimleri öğretmenlerinin BİLSEM'deki görev süreleri göz önüne alındığında sadece bir öğretmenin 10 yıllık tecrübeye sahip olması diğer öğretmenlerin ise 1-4 yıldır BİLSEM'de görev yapmaları ve özel yetenekli öğrenciler ile olan 
çalışmalarının daha az olması da yine çalışmanın sınırlılıkları içerinde değerlendirilebilir. Bu nedenle çalışmanın daha büyük ve daha fazla tecrübeye sahip çalışma gruplarıyla gerçekleştirilmesi bu sınırlılıkları ortadan kaldıracaktır.

\section{Kaynakça}

Akkanat, H. (1999). Üstün veya özel yetenekliler. M. R. Şirin, A. Kulaksızoğlu ve A. E. Bilgili (Ed.), Üstün yetenekli çocuklar: Seçilmiş makaleler kitabı içinde (s. 168-194). İstanbul: Çocuk Vakfı Yayınları.

Aktepe, V. ve Aktepe, L. (2009). Fen ve teknoloji öğretiminde kullanılan öğretim yöntemlerine ilişkin öğrenci görüşleri: Kırşehir BİLSEM örneği. Ahi Evran Üniversitesi Kırşehir Eğitim Fakültesi Dergisi, 10(1), 69-80.

Ayaydın, Y. ve Ün, D. (2018). Bilim ve sanat merkezleri öğretmenlerinin BİLSEM ve üstün yetenekli öğrencilerin eğitimine yönelik görüşleri. Amasya Üniversitesi Ĕ̆itim Fakültesi Dergisi, 7(1), 121-155.

Baltac1, A. (2018). Nitel araştırmalarda örnekleme yöntemleri ve örnek hacmi sorunsalı üzerine kavramsal bir inceleme. Bitlis Eren Üniversitesi Sosyal Bilimler Enstitüsü Dergisi, 7(1), 231274.

Bedur, S., Bilgiç, N. ve Taşlıdere, E. (2015). Özel (üstün) yetenekli öğrencilere sunulan destek eğitim hizmetlerinin değerlendirilmesi. Hasan Âli Yücel Ĕ̆itim Fakültesi Dergisi, 12(1), 159175.

Bildiren, A. ve Türkkani, B. (2013). Üstün yetenekli öğrencilerin perspektifinden bilim ve sanat merkezlerinin hoş ve hoş olmayan özellikleri ve değişiklik talepleri. Üstün Yetenekliler Eğitimi ve Araştırmaları Dergisi (UYAD), 1(2), 128-135.

Coşkun, İ., Dündar, Ş. ve Parlak, C. (2014). Türkiye'de özel eğitim alanında yapılmış lisansüstü tezlerin çeşitli değişkenler açısından incelenmesi (2008-2013). Ege Eğitim Dergisi, 15(2), 375-396.

Creswell, J. W. (2016). Nitel araştırma yöntemleri: Beş yaklaşıma göre nitel araştırma ve araştırma deseni (M. Bütün ve S. B. Demir, Çev.). Ankara: Siyasal Kitabevi.

Demirel, Ö. (2003). Kuramdan uygulamaya eğitimde program geliştirme. Ankara: Pegem Yayıncılık.

Erdoğan, S. C. ve Kahveci, N. G. (2015). Farklılaştırılmış fen ve teknoloji öğretiminin üstün zekâlı ve yetenekli öğrencilerin tutumlarına etkisi. Hasan Âli Yücel Eğitim Fakültesi Dergisi, 12(1), 191-207.

Gürsakal, S. (2012). PISA 2009 öğrenci başarı düzeylerini etkileyen faktörlerin değerlendirilmesi. Süleyman Demirel Üniversitesi İktisadi ve İdari Bilimler Fakültesi Dergisi, 17(1), 441-452.

Kahyaoğlu, M. ve Pesen, A. (2013). Üstün yetenekli öğrencilerin fen ve teknolojiye yönelik tutumları, öğrenme ve motivasyon stilleri arasındaki ilişki. Türk Üstün Zekâ ve Eğitim Dergisi, $3(1), 38-49$.

Kaptan, F. ve Korkmaz, H. (1999). Ilköğretimde fen bilgisi öğretimi: Illköğretimde etkili öğretme ve öğrenme ögretmen el kitabı. Ankara: Milli Eğitim Bakanlığı.

Kırcaali-İftar, G. (1998). Kaynaştırma ve destek özel eğitim hizmetleri. Eskişehir: Anadolu Üniversitesi Açıköğretim Fakültesi Yayınları.

Kontaş, H. ve Yağcl, E. (2016). BİLSEM öğretmenlerinin program geliştirme ihtiyaçlarına ilişkin geliştirilen programın etkililiği. Abant İzzet Baysal Üniversitesi Eğitim Fakültesi Dergisi, 16(3), 902-923.

Merriam, S. B. (2013). Nitel araştırma: Desen ve uygulama için bir rehber (S. Turan, Çev.). Ankara: Nobel Yayın Dağıtım. 
Mertol, H., Doğdu, M. ve Yılar, B. (2013). Üstün zekâlı ve yetenekli öğrencilerin sosyal bilgiler dersine ilişkin metaforik algıları. Üstün Yetenekliler Eğitimi ve Araştırmaları Dergisi (UYAD), 1(3), 176-183.

MEB (2015). Bilim ve sanat merkezleri yönergesi. https://orgm.meb.gov.tr/meb_iys_dosyalar/2015_09/18101802_bilimvesanatmerkezleriyn ergesi.pdf adresinden erişilmiştir.

MEB (2016). Bilim ve sanat merkezleri yönergesi.

https://orgm.meb.gov.tr/meb_iys_dosyalar/2016_10/07031350_bilsem_yonergesi.pdf adresinden erişilmiştir.

MEB (2013). Özel yetenekli bireylerin eğitimi strateji ve uygulama kılavuzu. Ankara: Özel Eğitim ve Rehberlik Hizmetleri Genel Müdürlüğü.

Okur, A. ve Özsoy, Y. (2013). Üstün zekâlı öğrencilerin Türkçe dersine yönelik tutumlarının incelenmesi: Bartın BİLSEM örneği. Eğitimde Kuram ve Uygulama, 9(3), 254-264.

Satmaz, İ. ve Gencel, İ. E. (2016). Bilim ve sanat merkezlerinde görevlendirilen öğretmenlerin hizmet içi eğitim sorunu. Dokuz Eylül Üniversitesi Buca Ĕ̆itim Fakültesi Dergisi, 42(2016), 59-73.

Sözbilir, M. (2009). Nitel veri analizi. https://fenitay.files.wordpress.com/2009/02/1112-nitelarac59ftc4b1rmada-veri-analizi.pdf adresinden erişilmiştir.

Şimşek, N. (2002). BİG 16 öğrenme biçimleri envanteri. Eğitim Bilimleri ve Uygulama Dergisi, 1(1), 33-47.

Tereci, H., Aydın, M. ve Orbay, M. (2008, Mayıs). Bilim ve sanat merkezlerine devam eden öğrencilerin fen tutumlarının incelenmesi: Amasya BİLSEM Örneği. Üstün Zekâlı ve Yetenekli Çocuklar Kongresi, Ankara.

TDK (2018). Eğitim.

http://www.tdk.gov.tr/index.php?option=com_yanlisveview=yanlisvekelimez=138 adresinden erişilmiştir.

Yıldırım, A. ve Şimşek, H. (2006). Sosyal bilimlerde nitel araştırma yöntemleri. Ankara: Seçkin Yayıncll1k.

\section{Ek A. Görüşme Soruları}

1. Özel yetenekli öğrencileri nasıl tanımlarsınız?

- $\quad$ Fen bilimleri dersinde özel yetenekli öğrenciyi nasıl tanırsınız?

2. Özel yetenekli öğrenciler fen bilimleri dersinde hangi konulara daha çok ilgi duyuyorlar?

3. Özel yetenekli öğrencilerin fen eğitimi için nasıl bir ortam (laboratuvar, gezi gözlem vb. ) sağlanmalıdır?

4. Özel yetenekli öğrenciler için normalden farklı bir öğretim yöntem ve tekniği mi kullanıyorsunuz?

- Bu öğretim yöntem ve tekniklerden hangileri özel yetenekli öğrencilere fen bilimleri dersinde uygulanabilir?

- Seçtiğiniz bir yöntemi bize anlatabilir misiniz ve neden bu yöntemi seçtiğinizi bizimle paylaşır misinız?

5. Özel yetenekli öğrencilerin gelişimini ölçen yöntemler nelerdir?

- BILSEM'lerde fen bilimleri dersinde ilerlemeyi ölçen ne gibi ölçekler (yöntemler) kullanmaktasiniz?

- Kullanılan bu ölçekler özel yetenekli öğrencilerin gelişimine ne düzeyde katkı sağlamaktadir?

6. Özel yetenekli öğrenciler için fen eğitiminde önerdiğiniz görüşler nelerdir? 